\title{
Physiological Disorders of Landscape Palms ${ }^{1}$
}

Timothy K. Broschat ${ }^{2}$

Physiological disorders are those caused by various environmental factors, rather than biological agents. Nutrient deficiencies are typically included within this category, but are discussed in other publications See: $\mathrm{N}$ deficiency, $\mathrm{K}$ deficiency, $\mathrm{Mg}$ deficiency, Mn deficiency, Fe deficiency, B deficiency.

\section{Boron Toxicity}

\section{Symptoms}

Older leaflets of affected palms have light tan necrotic tips, the necrosis gradually spreading up the leaflets (Figure 1).

\section{Cause}

This disorder is caused by excessive B in the soil or irrigation water.

\section{Occurrence}

Boron toxicity is rare in areas that have high rainfall, but can occur in drier climates (e.g., central California). It can occur anywhere if excessive B fertilizers are applied or if high B water is used for irrigation. Boron toxicity has been artificially induced in Dypsis lutescens (areca palm) and

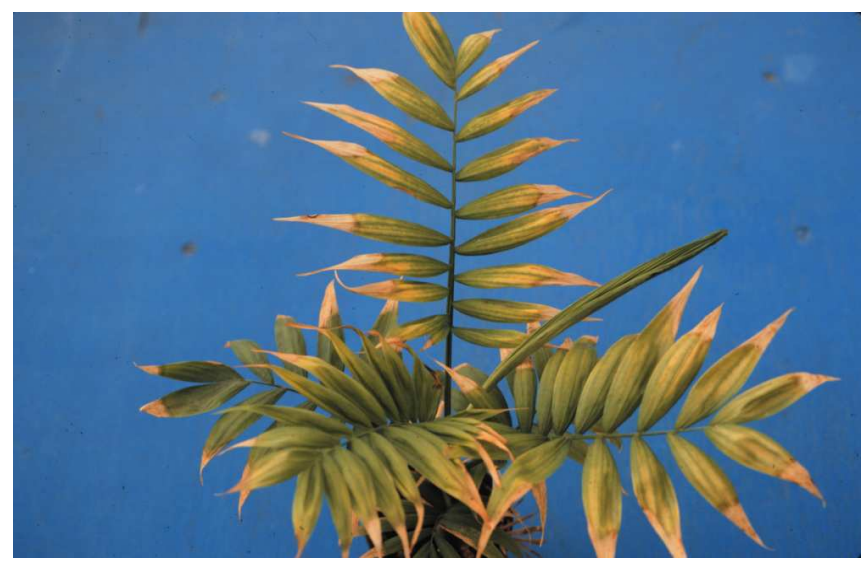

Figure 1. Boron toxicity of Chamaedorea elegans. Credits: T.K. Broschat

Chamaedorea elegans (parlor palm), but many other species are probably also susceptible. It has never been documented in Florida landscape palms, but when slow release B fertilizers are used, it could be a distinct possibility.

\section{Diagnostic Techniques}

Leaf analysis for B content along with visual symptoms are needed to diagnose B toxicity in palms. Generally, leaf B concentrations greater than 100 ppm are considered toxic for palms. When sampling for leaf analysis, select 4 to 6 central leaflets from the youngest fully-expanded leaf.

1. This document is ENH1011, one of a series of the Environmental Horticulture Department, Florida Cooperative Extension Service, Institute of Food and Agricultural Sciences, University of Florida. Original publication date September 2005. Visit the EDIS Web Site at http://edis.ifas.ufl.edu.

2. Timothy K. Broschat is Professor, Environmental Horticulture Department, Fort Lauderdale Research and Education Center, Institute of Food and Agricultural Sciences, University of Florida, Fort Lauderdale, FL 33314

The Institute of Food and Agricultural Sciences (IFAS) is an Equal Opportunity Institution authorized to provide research, educational information and other services only to individuals and institutions that function with non-discrimination with respect to race, creed, color, religion, age, disability, sex, sexual orientation, marital status, national origin, political opinions or affiliations. U.S. Department of Agriculture, Cooperative Extension Service, University of Florida, IFAS, Florida A. \& M. University Cooperative Extension Program, and Boards of County Commissioners Cooperating. Larry Arrington, Dean 


\section{Management}

Avoid using water high in B or excessive rates of high B fertilizers. Palms suffering from B toxicity can be treated by leaching the soil heavily.

\section{Selected References}

Marlatt, R. B. 1978. Boron deficiency and toxicity symptoms in Ficus elastica and Chrysalidocarpus lutescens. HortScience 13:442-443.

\section{Cold Injury}

\section{Symptoms}

Primary symptoms include extensive necrosis of the foliage (Figures 2 and 3). Necrosis is not necessarily confined to leaflet tips. Symptoms may include those of water stress such as wilting. Unhardy palms may be killed. Secondary symptoms include bacterial bud rot (Figure 5) and transient micronutrient deficiencies (Figure 6).

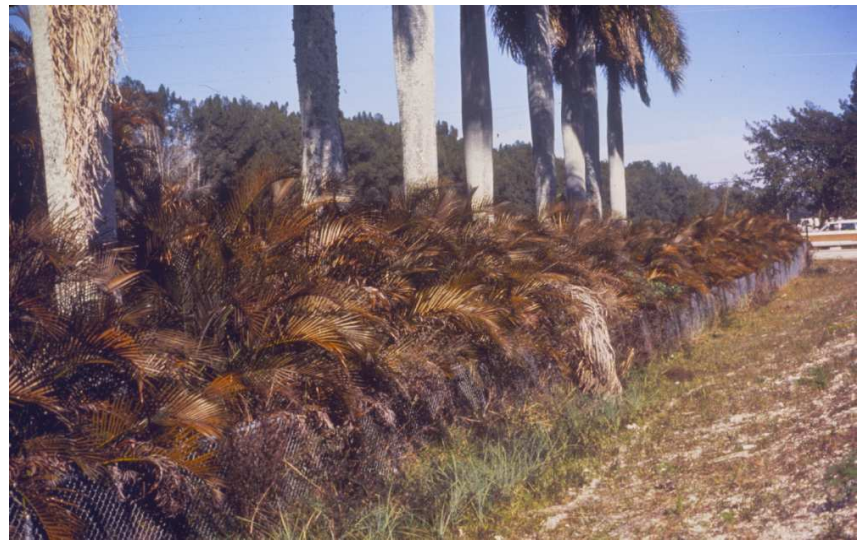

Figure 2. Freeze damage on Dypsis lutescens. Credits: T.K. Broschat

\section{Cause}

Exposure to temperatures below that to which palms are acclimated will cause injury. Palms differ greatly with respect to their cold tolerance, both within and among species. Within a species, susceptibility to cold injury is reduced by gradually acclimating palms to cooler temperatures. Temperatures of $50^{\circ} \mathrm{F}$ or lower can injure some tropical palms (Figure 4), while some temperate species can withstand freezing temperatures with no

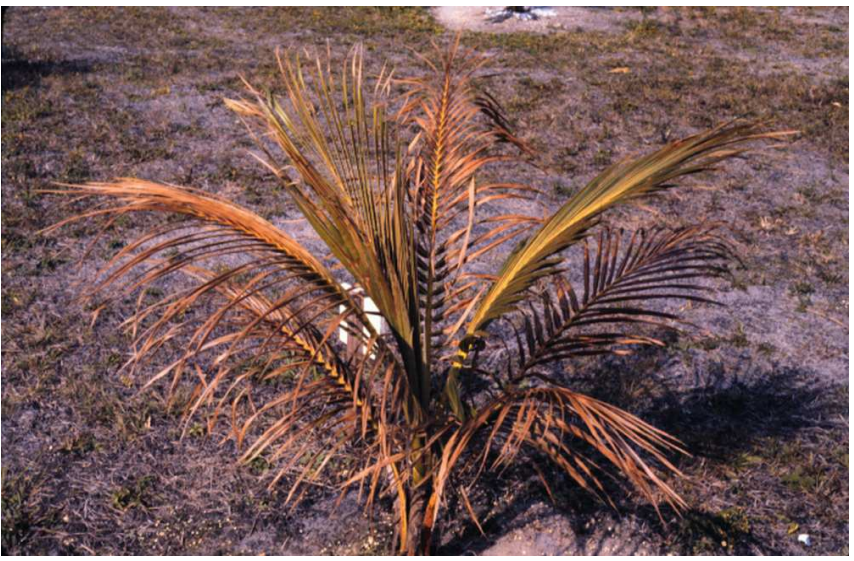

Figure 3. Freeze damage on Cocos nucifera. Credits: T.K. Broschat

injury. Palms stressed by cold temperatures are very susceptible to bacterial bud rot (Figure 5) and may later show signs of micronutrient deficiencies, such as $\mathrm{Mn}$, due to lower root activity at cooler temperatures (Figure 6).

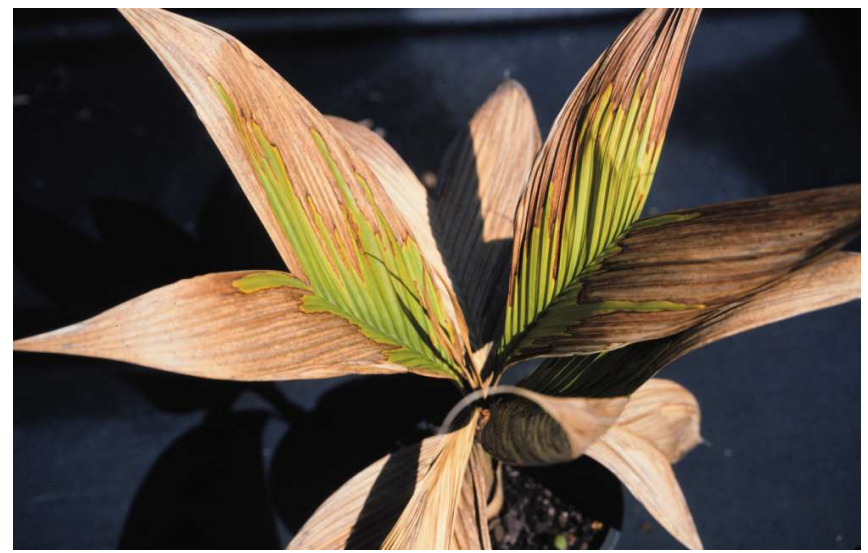

Figure 4. Chilling injury on Geonoma sp. caused by temperatures below $10^{\circ} \mathrm{C}$. Credits: T.K. Broschat

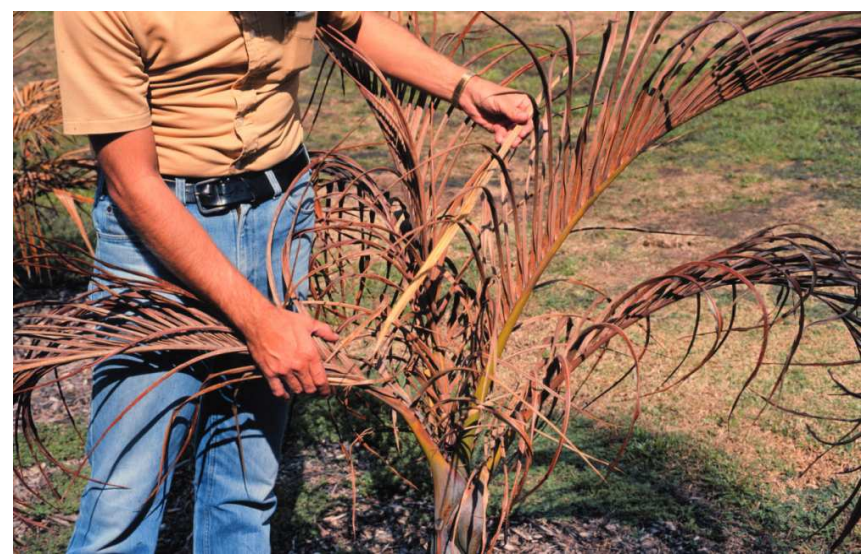

Figure 5. Secondary bud rot on Hyophorbe verschafeltii following severe freeze. Credits: T.K. Broschat 


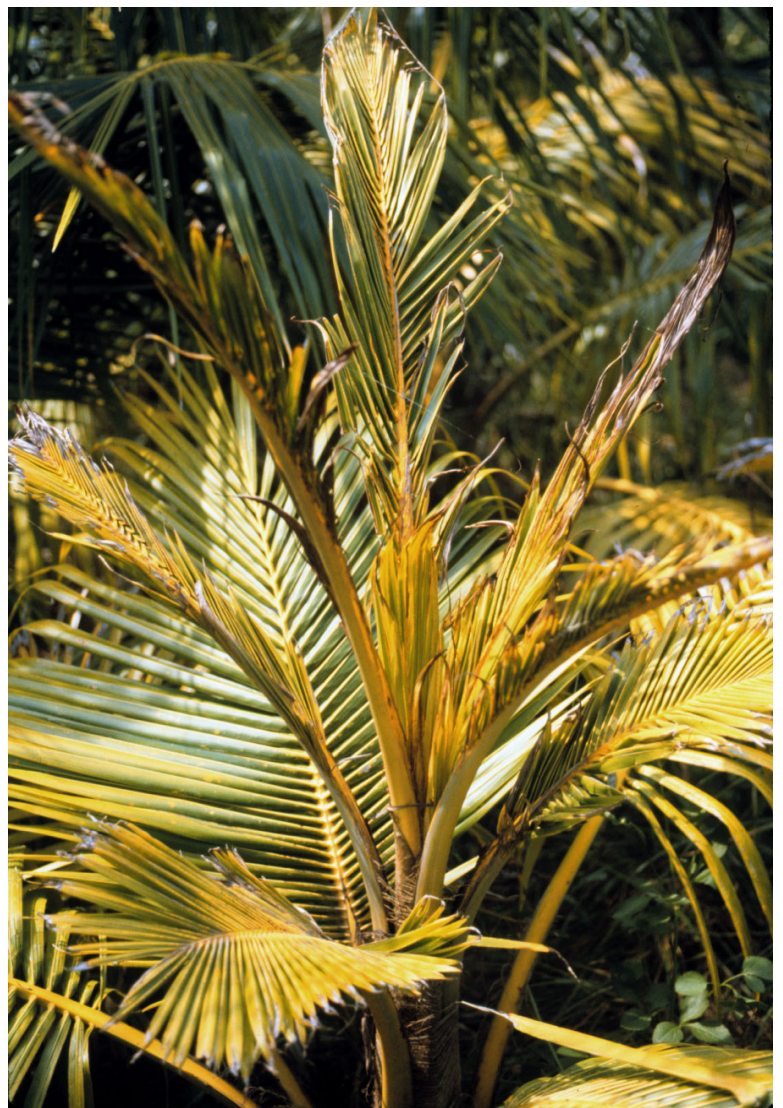

Figure 6. Micronutrient deficiency symptoms (probably B and/or Mn deficiencies) induced by cold temperatures in Cocos nucifera. Credits: T.K. Broschat

Damage caused by hard freezes will affect all parts of a palm and all susceptible palms within an area, whereas damage caused by a frost will likely be spotty in distribution and may affect only exposed parts of individual palms.

\section{Occurrence}

All species of palms are susceptible to cold temperature, but the temperature at which injury will occur is dependent on the species and the extent of its cold acclimation.

\section{Diagnostic Techniques}

Symptomology plus knowledge of temperatures to which palms may have been exposed are sufficient for diagnosis of cold damage.

\section{Management}

Grow only palms that are adapted to your climate. Small, valuable palms can be covered during occasional freezes. Palms in containers can be moved indoors for protection during cold weather. Flooding of palm field nurseries can help prevent freeze damage. Running overhead irrigation continuously, starting before the temperature drops below freezing and ending only after the temperature is above freezing, is a good alternative for both container and field grown palms. Since death of the palm is often caused by secondary bacterial bud rots, rather than the cold temperature itself, treatment for bacterial bud rot may improve the chances for palm survival. Suggested post-freeze treatments include removing rotted spear leaves to allow the bud area to dry out and drenching the bud with a copper-containing fungicide. Do not remove any foliage that is not completely necrotic. To prevent transient $\mathrm{Mn}$ deficiency, apply manganese sulfate in the fall to the soil. A foliar spray with manganese sulfate in the spring may help Mn-deficient palms recover more quickly.

\section{Selected References}

Larcher, W. and A. Winter. 1981. Frost susceptibility of palms: Experimental data and their interpretation. Principes 25:143-152.

Meerow, A.W. 1994. Field production of palms. Acta Hortic. 360:181-188.

\section{Excessive Water Uptake (trunk splitting)}

\section{Symptoms}

Palms that take up excessive amounts of water may have trunks with deep longitudinal splits. These trunks will often appear waterlogged and may be covered with mosses, lichens, algae, and other epiphytes (Figure 7).

\section{Cause}

This trunk splitting may be due to greater water uptake and expansion of the soft-walled parenchyma cells that predominate in the central portion of most palm stems than in the peripheral tissue that is dominated by rather rigid vascular and fiber cells. 


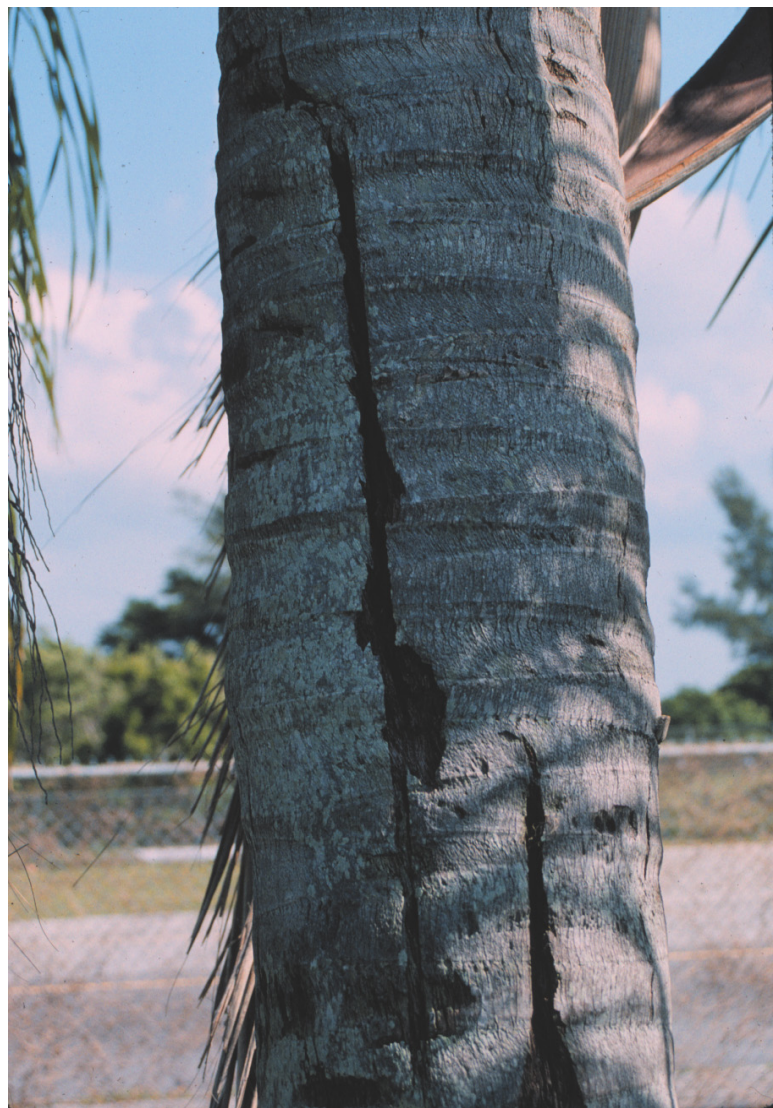

Figure 7. Vertical trunk splitting in Syagrus romanzoffiana caused by excessive water uptake.

\section{Occurrence}

This problem is most common in areas that typically receive high rainfall, but can also occur in drier areas in response to extended wet weather.

\section{Diagnostic Techniques}

Visual symptoms should be sufficient to diagnose this disorder.

\section{Management}

The occurrence of this disorder cannot be predicted, prevented, or treated. The structural strength of a palm is usually not significantly weakened by minor stem cracking, but cracks extending half way through or more could substantially reduce trunk strength.

\section{Foliar Salt Injury}

\section{Symptoms}

Foliar salt injury appears as desiccation of the foliage. Symptoms may be more severe on the exposed windward side of palms growing near the ocean (Figure 8). Some palms may be killed by salt spray.

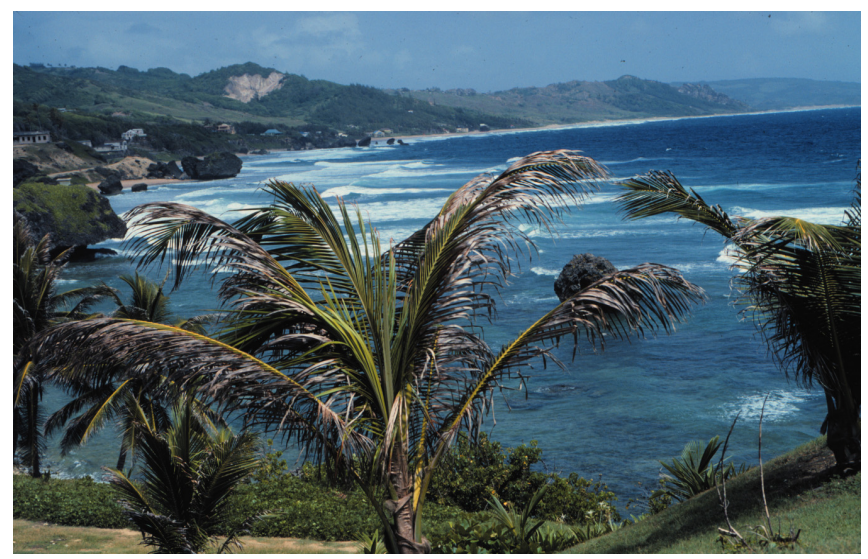

Figure 8. Foliar salt injury on Cocos nucifera caused by airborne salt spray. Credits: T.K. Broschat

\section{Cause}

Salt spray from the ocean on the foliage can cause desiccation of leaves unless it is quickly rinsed off by rainfall or other fresh water.

\section{Occurrence}

Foliar salt injury is fairly common along seashores during dry periods with strong onshore winds. Many species are affected by salt spray, but Cocos nucifera (coconut palm), Serenoa repens (saw palmetto), Allagoptera arenaria, Hyophorbe spp., Coccothrinax spp., Thrinax spp., and Pseudophoenix spp. are most tolerant of seashore conditions.

\section{Diagnostic Techniques}

Visual symptoms are usually sufficient to diagnose this problem.

\section{Management}

Plant only salt-tolerant species of palms in areas exposed to salt spray. If strong onshore winds persist, foliage of sensitive palms should be rinsed with fresh water soon after these conditions subside. 


\section{Hapaxanthic Flowering}

\section{Symptoms}

Stems of flowering and fruiting palms gradually decline and die (Figures 9 and10). Flowering may be terminal, or along the trunk, the latter beginning either at the top or at the bottom, depending on the species.

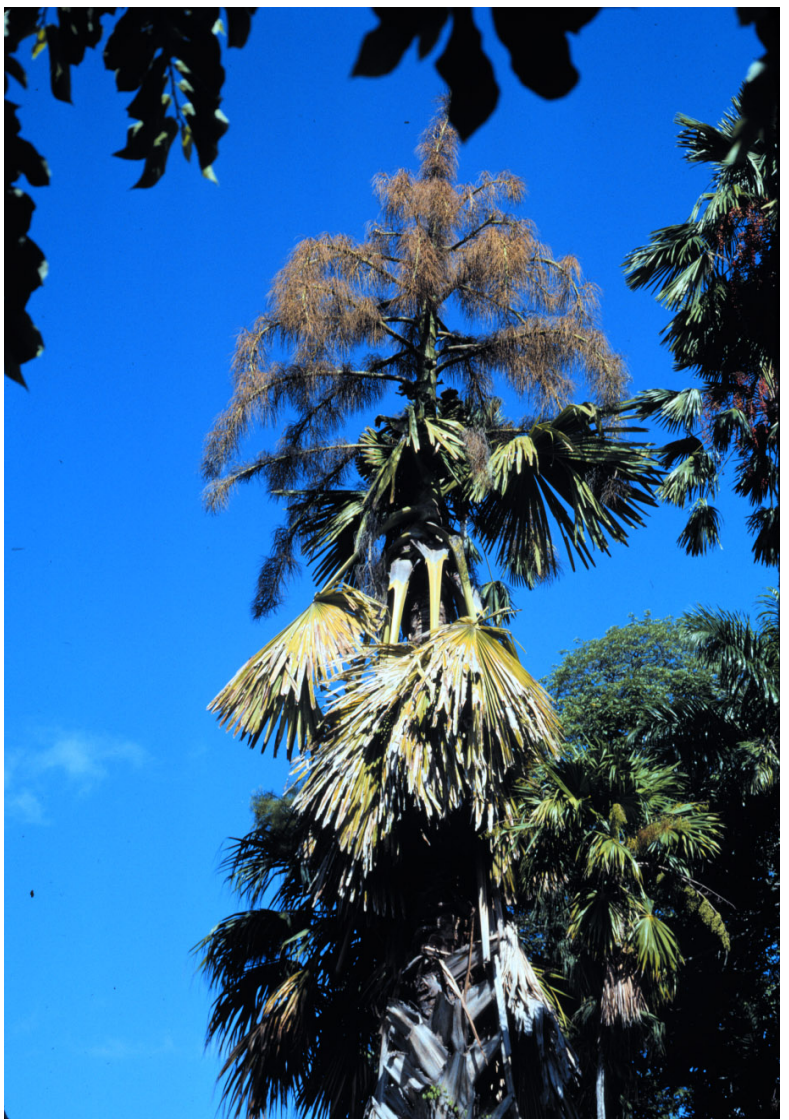

Figure 9. Hapaxanthic flowering in Corypha elata (talipot palm). Credits: T.K. Broschat

\section{Cause}

In haxapanthic palm species, stems normally die after flowering and fruiting.

\section{Occurrence}

Hapaxanthic flowering occurs in Caryota spp., Arenga spp., Corypha spp., Wallichia spp., Nannorhops ritchiana, some Metroxylon spp., and Raphia spp.

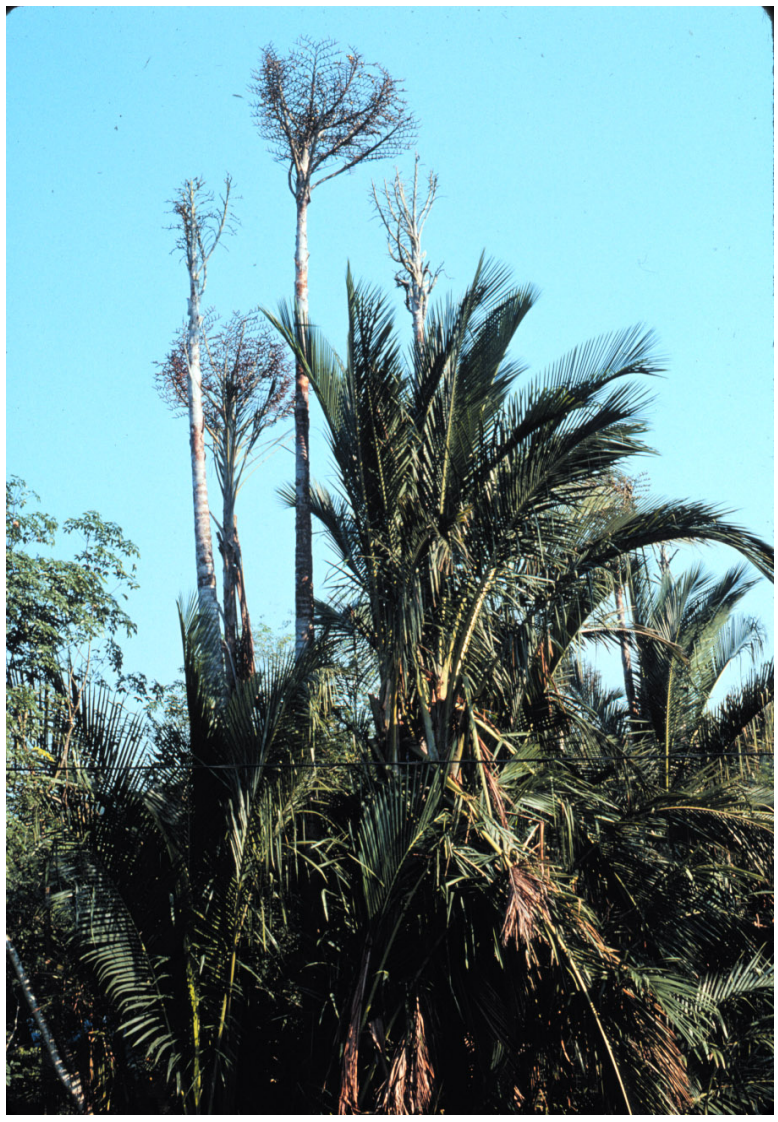

Figure 10. Hapaxanthic flowering in Metroxylon sagu. Credits: T.K. Broschat

\section{Diagnostic Techniques}

The presence of flowers or fruits in the above palm species is sufficient to diagnose this problem.

\section{Management}

Plant only pleonanthic palms for long-term landscape use. Pleonanthic palms do not die after flowering and fruiting.

\section{Herbicide Toxicity}

\section{Symptoms}

Symptoms of herbicide toxicity vary with the class of herbicide used. Among postemergent herbicides, glyphosate injury appears as distortion and reduction in the size of new leaves (Figure 11). New leaflets may show some necrosis. Paraquat or diquat injury appears as desiccation of the foliage contacted by the herbicide. Phenoxy herbicides such as 2,4-D cause distortion of the foliage and contortion of petioles. Although these postemergent 
herbicides can be fatal, palms often outgrow these symptoms and eventually resume normal growth.

Preemergent herbicides typically cause injury to newly emerging foliage. Symptoms include new leaf dieback, chlorosis, stunting, and varying patterns of necrosis (Figure 12). Death of the meristem or bud is common (Figure 13). In palms treated with metolachlor, symptoms often include the production of side shoots in addition to new leaf stunting, necrosis, and distortion (Figure 14). Large palms growing in landscapes can also be affected by preemergent herbicides, often fatally.

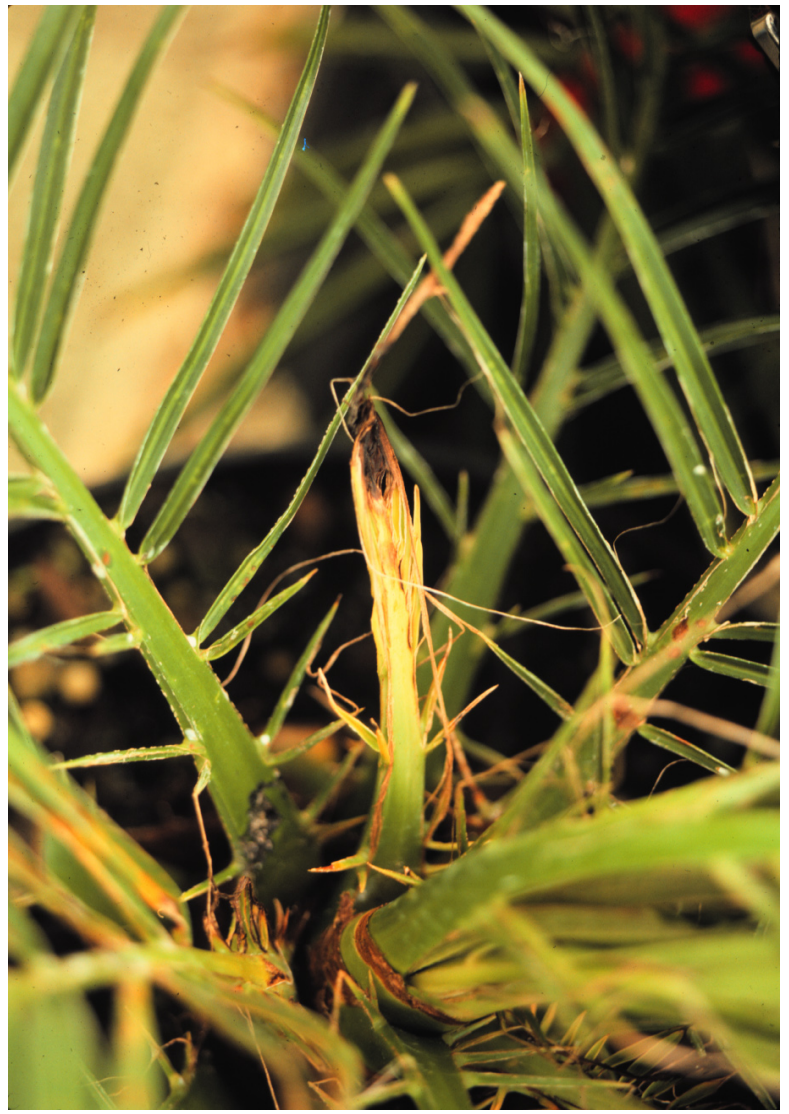

Figure 11. Glyphosate injury on Phoenix roebelenii (pygmy date palm). Credits: T.K. Broschat

\section{Cause}

Herbicides applied to the foliage or soil can be absorbed by palms with variable results.

\section{Occurrence}

Injury due to preemergent herbicides is fairly common where these are applied to container-grown palms, but these products can also affect mature

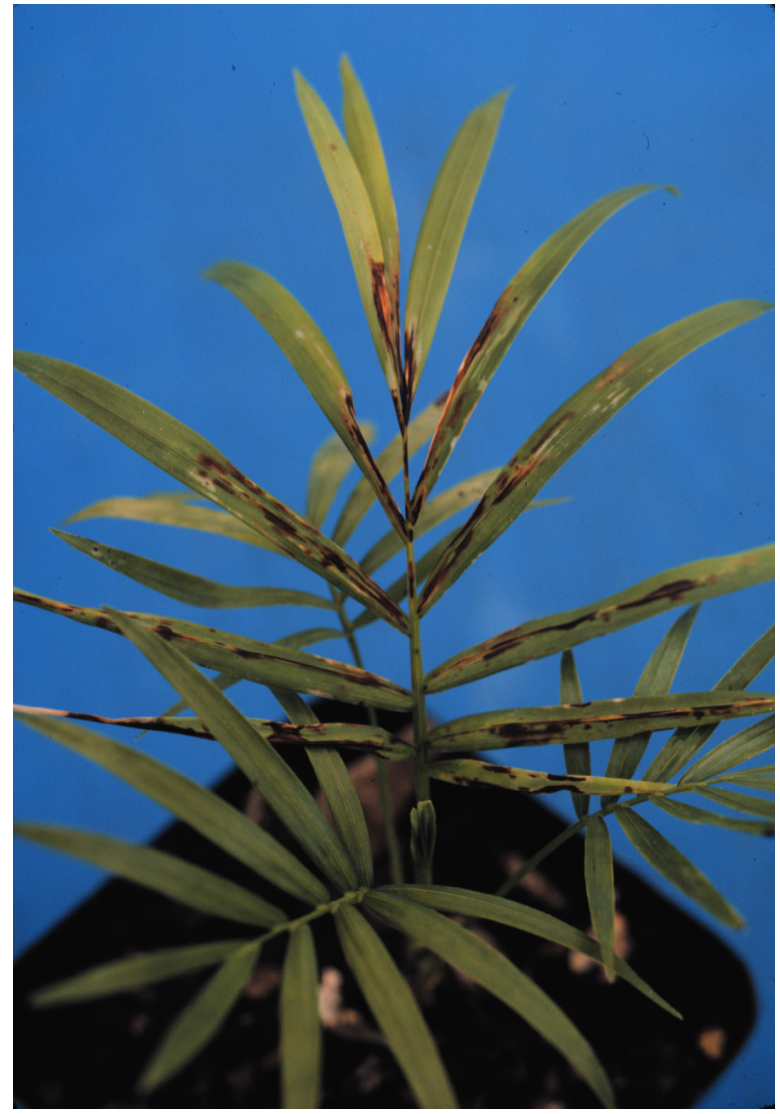

Figure 12. Preemergent herbicide (pendimethalin plus oxyfluorfen) injury on Chamaedorea elegans. Credits: T.K. Broschat

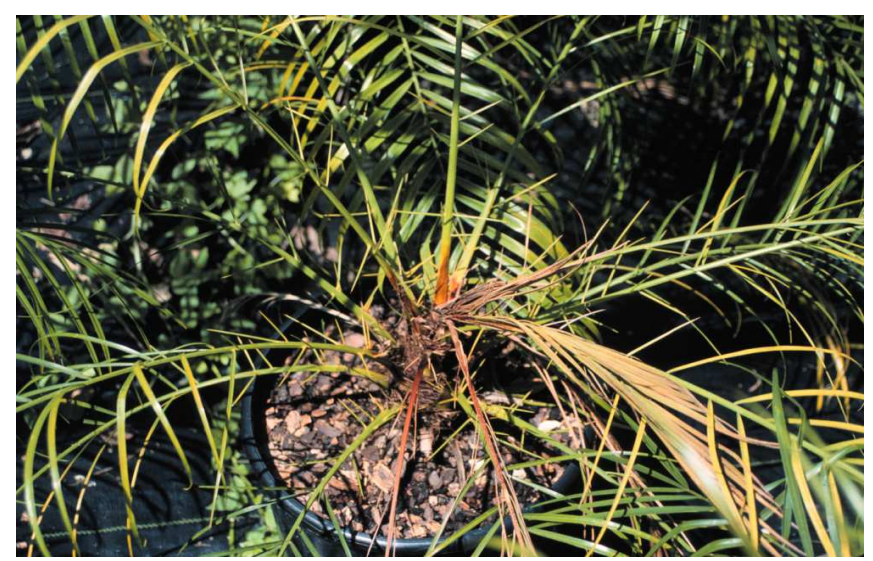

Figure 13. Preemergent herbicide (trifluralin plus isoxaben) injury on Phoenix roebelenii. Credits: T.K. Broschat

palms in the landscape that have been treated. Although some studies have shown certain preemergent products to be quite safe when used on palms at recommended rates, other studies have shown injury from these same products when applied to the same species at similar rates. Clearly there are 


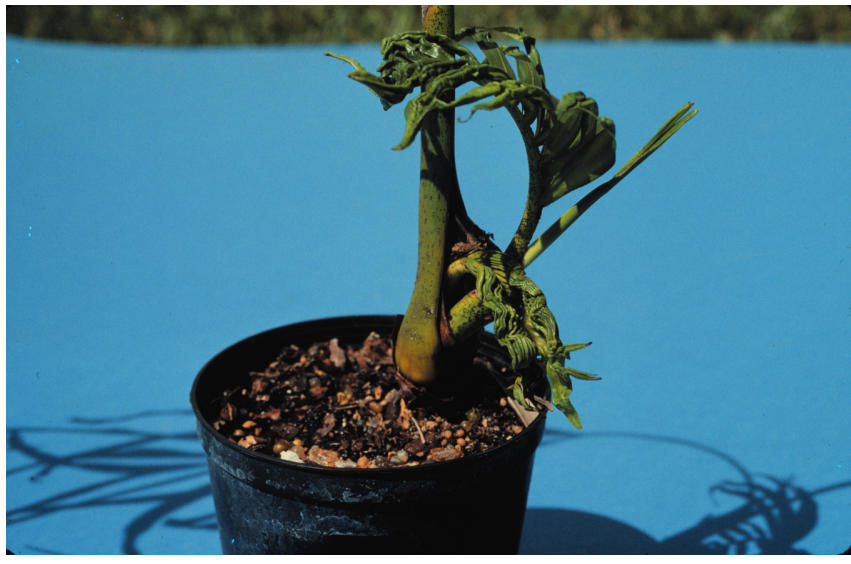

Figure 14. Preemergent herbicide (metolachlor) injury on Dypsis lutescens. Note the production of side shoots. Credits: T.K. Broschat

some environmental factors affecting the activity of these materials that are not understood at this time.

Postemergent herbicide damage is less common since these products are often used as directed sprays around the trunks of mature palms in field nurseries or landscapes and seldom contact the foliage. Most palms, Cocos nucifera in particular, are highly resistant to injury by glyphosate.

\section{Diagnostic Techniques}

Visual symptoms, plus a knowledge of treatment history, are needed to diagnose herbicide toxicity. Although leaf analysis can be used to test for suspected herbicides in the foliage, it is slow, expensive, and can only test for a single herbicide at a time. Furthermore, the results may not necessarily tell you if the concentrations found in the foliage are sufficiently high to have caused the symptoms you observed. Contact the laboratory that will conduct the analysis to determine which tissue they would like you to send them.

\section{Management}

Do not allow any herbicide to contact palm foliage. Postemergent herbicides such as glyphosate, gluphosinate-ammonium, paraquat, and diquat can safely be applied as directed sprays around the trunks of mature palms. Preemergent herbicides should be used with great caution around palms. Products such as metolachlor are invariably toxic to palms, but most other products are unpredictable in their effects and may be safe one time, but highly damaging at another.

\section{Selected References}

Broschat, T.K. 2000. Phytotoxicity and longevity of twenty-two preemergent herbicides used on three species of container-grown palms. HortTechnology 10:597-603.

Donselman, H. and T.K. Broschat. 1986.

Phytotoxicity of several pre- and post-emergent herbicides on container-grown palms. Proc. Fla. St. Hort. Soc. 99:273-274.

Meerow, A.W. and T.K. Broschat. 1991. Phytotoxicity of the preemergent herbicide metolachlor on containerized palms. Foliage Digest 17(9):6.

Neel, P.L. 1977. Effects of oxadiazon preemergence herbicide on weed control and growth of sixteen species of containerized ornamental plants. Proc. Fla. St. Hort. Soc. 90:353-355.

\section{High Soil Soluble Salts}

\section{Symptoms}

Palms suffering from high soil soluble salts usually have necrotic leaflet tips on older leaves (Figure 15). New foliage may express typical Fe deficiency symptoms or wilting due to reduced root surface area for nutrient and water absorption (Figure 16). Roots will often have necrotic tips or more extensive necrosis due to secondary root rots.

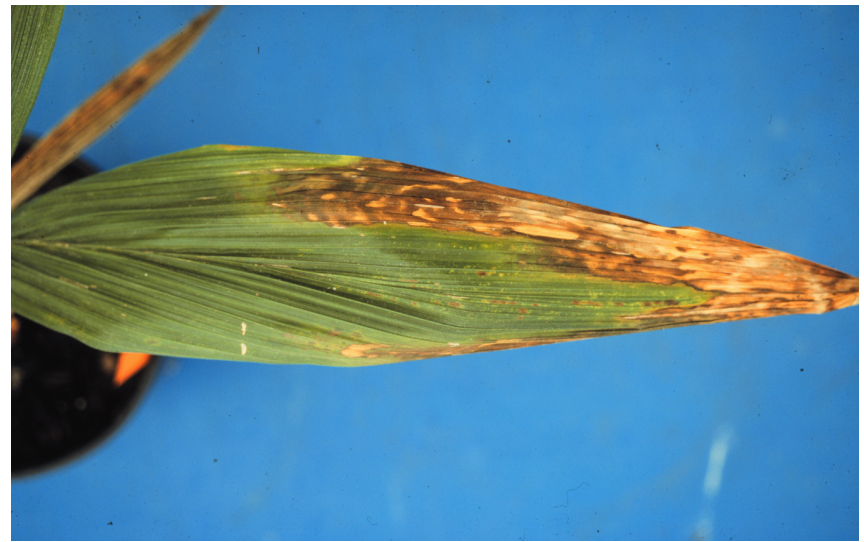

Figure 15. Older leaf of Syagrus romanzoffiana seedling suffering from high soil soluble salts. Credits: T.K. Broschat 


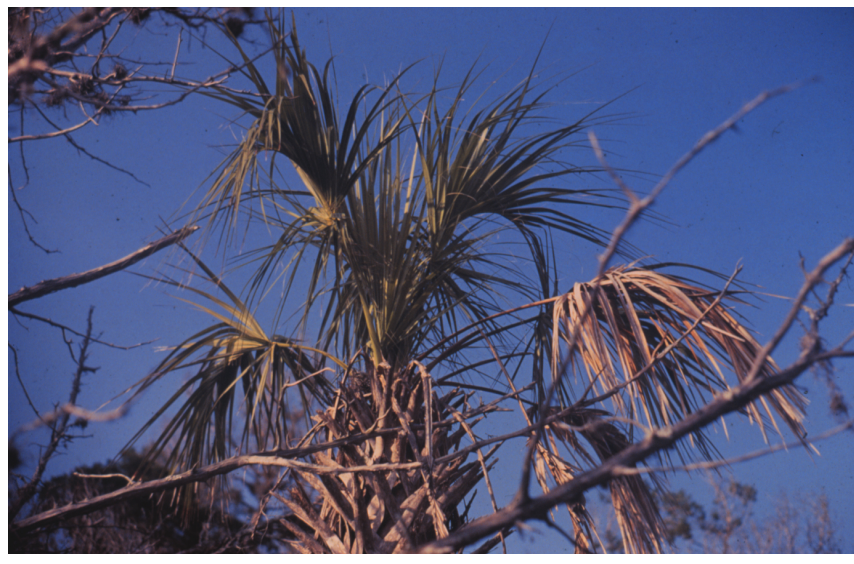

Figure 16. Salt injury on Sabal palmetto growing in area subject to salt water inundation. Credits: T.K. Broschat

\section{Cause}

High soil soluble salts can be caused by excessive fertilization or the use of saline irrigation water in both container production and in the landscape or field nursery. In landscapes or field nurseries, salt water intrusion in low lying coastal areas is another source of soil salts.

\section{Occurrence}

Soluble salts injury can occur under landscape conditions, particularly in drier climates where rainfall or irrigation is insufficient to leach out excess salts from the soil. Palm species differ greatly in their susceptibility to soluble salts injury. Cocos nucifera, Phoenix spp., Hyophorbe spp., Thrinax spp., Coccothrinax spp., Allagoptera arenaria, and Serenoa repens are highly tolerant of high soil soluble salts.

\section{Diagnostic Techniques}

Visual symptoms plus soil soluble salts analysis are needed to diagnose this disorder.

\section{Management}

Low salt fertilizers should be used and only at recommended rates. Some leaching of the container soil should occur at each irrigation to prevent the problem. If the problem is caused by saline irrigation water and a cleaner water source cannot be found, the soil should not be allowed to dry out and/or only salt tolerant species of palms should be grown. If the condition already exists, the soil should be leached thoroughly several times to remove excess salts.

\section{Selected References}

Furr, J.R. and C.L. Ream. 1968, Salinity effects on growth and salt uptake of seedlings of the date Phoenix dactylifera L. Proc. Amer. Soc. Hort. Sci. 92:268-273.

Koebernick, J. 1966. Salt tolerance in young palms. Principes 10:12-14.

\section{Improper Planting Depth}

\section{Symptoms}

Palms planted too deeply usually exhibit symptoms of root suffocation such as chlorosis from Fe or Mn deficiency, wilting or shriveling of the trunk, reduced canopy size, root rots, and ultimately death (Figures 17 and 18). Palms stressed from deep planting are also more attractive to boring insects such as Dinapetes wrightii in California or Rhynchophorus spp. or Metamasius spp. in more humid tropical areas.

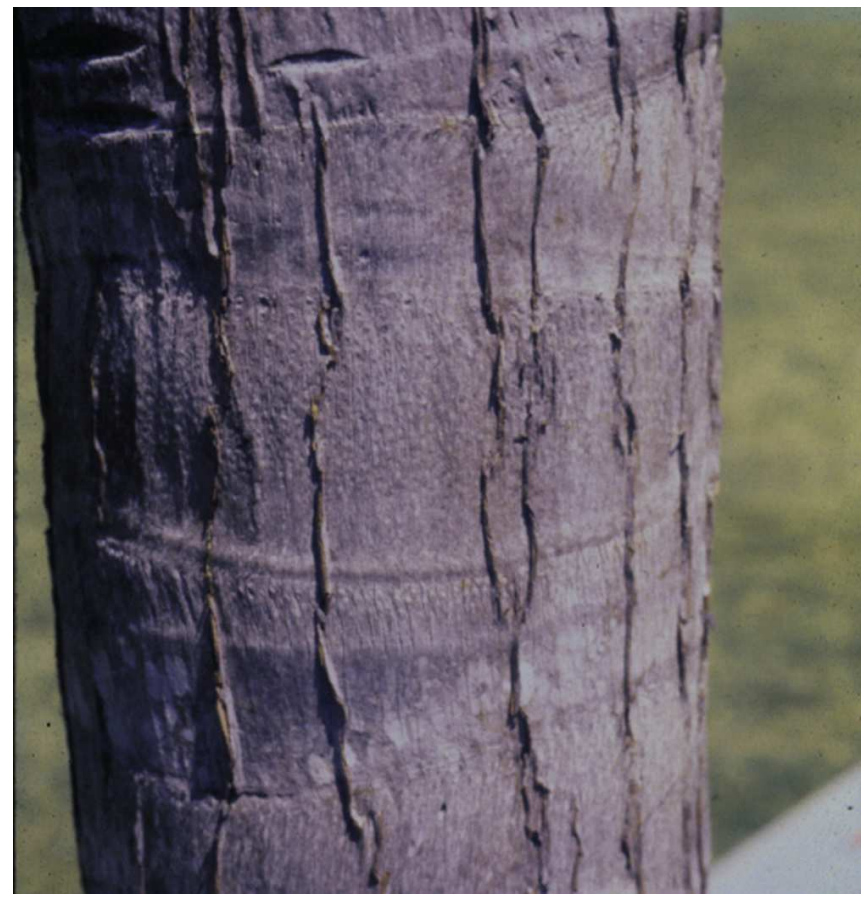

Figure 17. Shriveled trunk of Syagrus romanzoffiana caused by deep planting. Credits: T.K. Broschat

Palms planted too shallowly typically have their trunks elevated above the soil line and are totally supported by roots. Such palms in the landscape are often supported by only a few roots, while hundreds of new adventitious root initials remain in a state of 


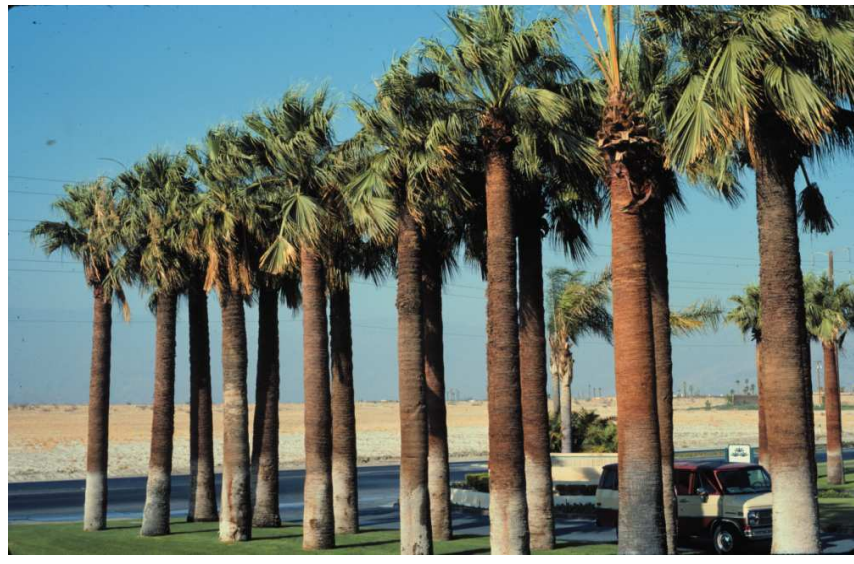

Figure 18. Washingtonia filifera planted at varying depths to achieve a uniform height. Note that at least one palm is dying from deep planting. Credits: T.K. Broschat

arrested development at the base of the trunk due to desiccation. Shallowly planted palms are structurally unsound and can easily topple over in moderate to high winds (Figure 19).

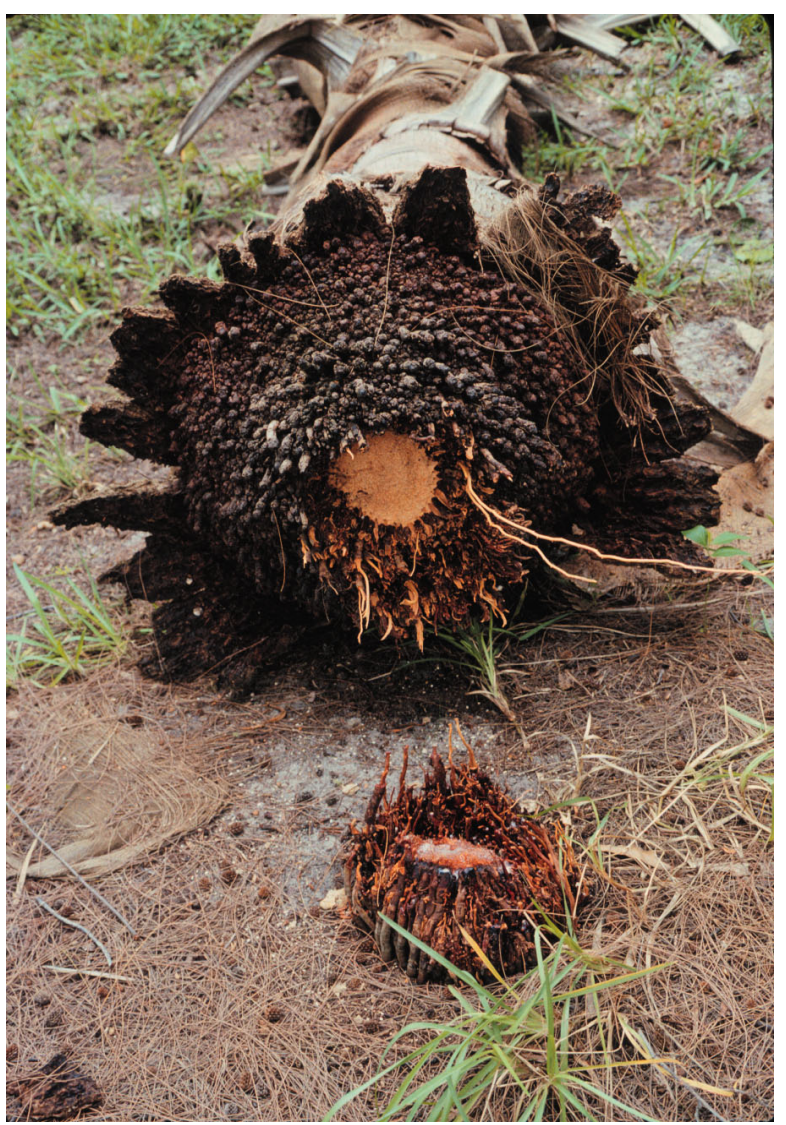

Figure 19. Cocos nucifera transplanted too shallowly. Credits: T.K. Broschat

\section{Cause}

Deep planting results in reduced root zone oxygen levels, which in turn reduces root respiration rates and ultimately the effectiveness of the root system in taking up nutrients and water. Planting of palm seedlings in containers as little as 1 inch too deep can result in chronic Fe deficiency symptoms and reduced growth rate. Aerial root initials extending up the base of old palm trunks will resume normal development if buried, but no root will ever develop from the trunk above this zone of active root initiation.

In shallow planted palms, newly emerging adventitious roots arising from the base of the stem axis are exposed to dry air, rather than moist soil and this dry environment inhibits their normal development. Only those roots already in the soil at the time of transplanting will ever support the palm and these are usually insufficient to support the weight of a large mature palm.

\section{Occurrence}

Deep planting is quite common when seedlings are planted into containers, but also occurs in the landscape when large specimen-sized palms are intentionally planted deeply for added support or to reduce the final height of a palm to a particular size. Shallow planting is primarily a problem when juvenile palms are transplanted either from small to large containers or from containers into the landscape.

\section{Diagnostic Techniques}

Deep planting is easily diagnosed by symptoms plus digging down into the soil to determine the depth of the root ball. The top of the root ball should be at ground level.

Shallow planting is obvious by the presence of an inverted cone-shaped trunk base covered with undeveloped root initials. These palms will show few roots actually penetrating into the soil. 


\section{Management}

Always plant large palms such that the swollen base of the stem is about 1 inch below the soil line. Palms planted too deeply should be dug up and replanted at the proper depth. Shallowly planted palms, if small, can be similarly replanted at the proper depth, but large, established palms can be stabilized by simply mounding up soil around the base of the undeveloped root initials at the base of the trunk. These root initials will quickly resume their growth down into the soil and firmly anchor the palm.

\section{Selected References}

Broschat, T.K. 1995. Planting depth affects survival, root growth and nutrient content of transplanted pygmy date palms. HortScience 30:1031-1032.

\section{Lightning}

\section{Symptoms}

Lightning injury symptoms are quite variable, but often include dark longitudinal streaks, bleeding, splitting of the trunk, and sudden collapse of the crown (Figures 20-22). Lightning strikes are usually fatal to palms.

\section{Cause}

This disorder is caused by lightning striking the palm.

\section{Occurrence}

Lightning injury is fairly common in areas receiving frequent electrical storms. Although tall palms are most susceptible, shorter palms adjacent to a struck palm can also be affected.

\section{Diagnostic Techniques}

Visual symptoms are usually sufficient for diagnosis. No other disorder can cause a perfectly healthy palm to collapse and die within a couple of days.

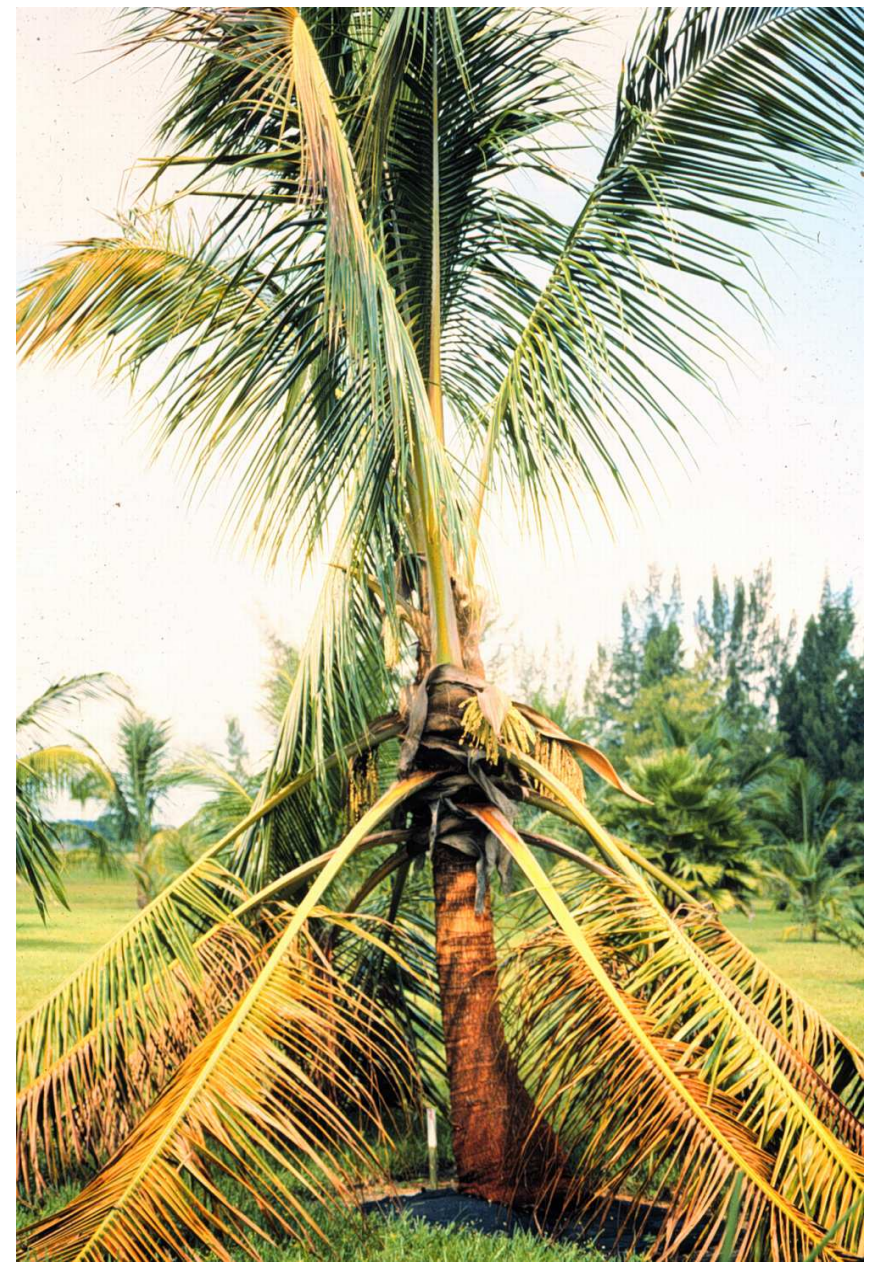

Figure 20. Rapid collapse of Cocos nucifera caused by lightning. Credits: T.K. Broschat

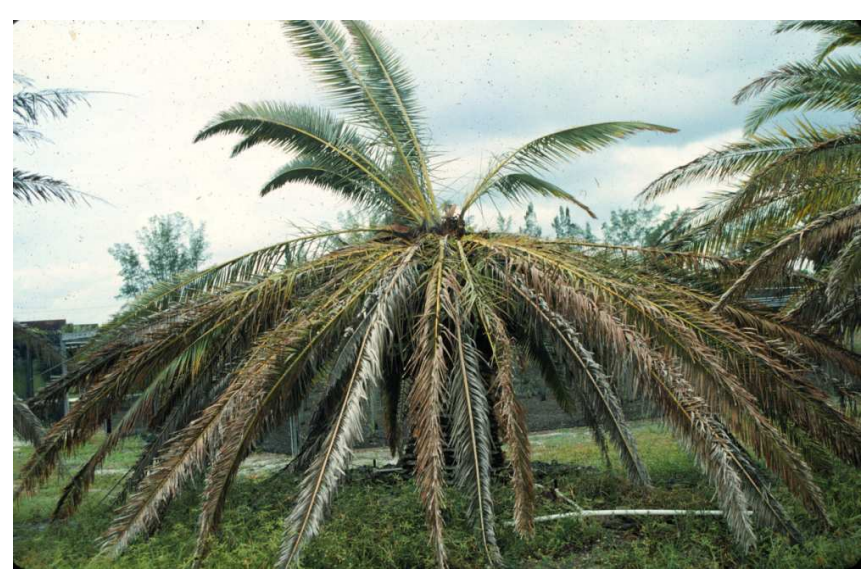

Figure 21. Lightning damage on Phoenix canariensis. Credits: T.K. Broschat

\section{Management}

Lightning injury cannot be treated and prevention by mounting lightning grounds within palm canopies is impractical for all but the most valuable of palms. 


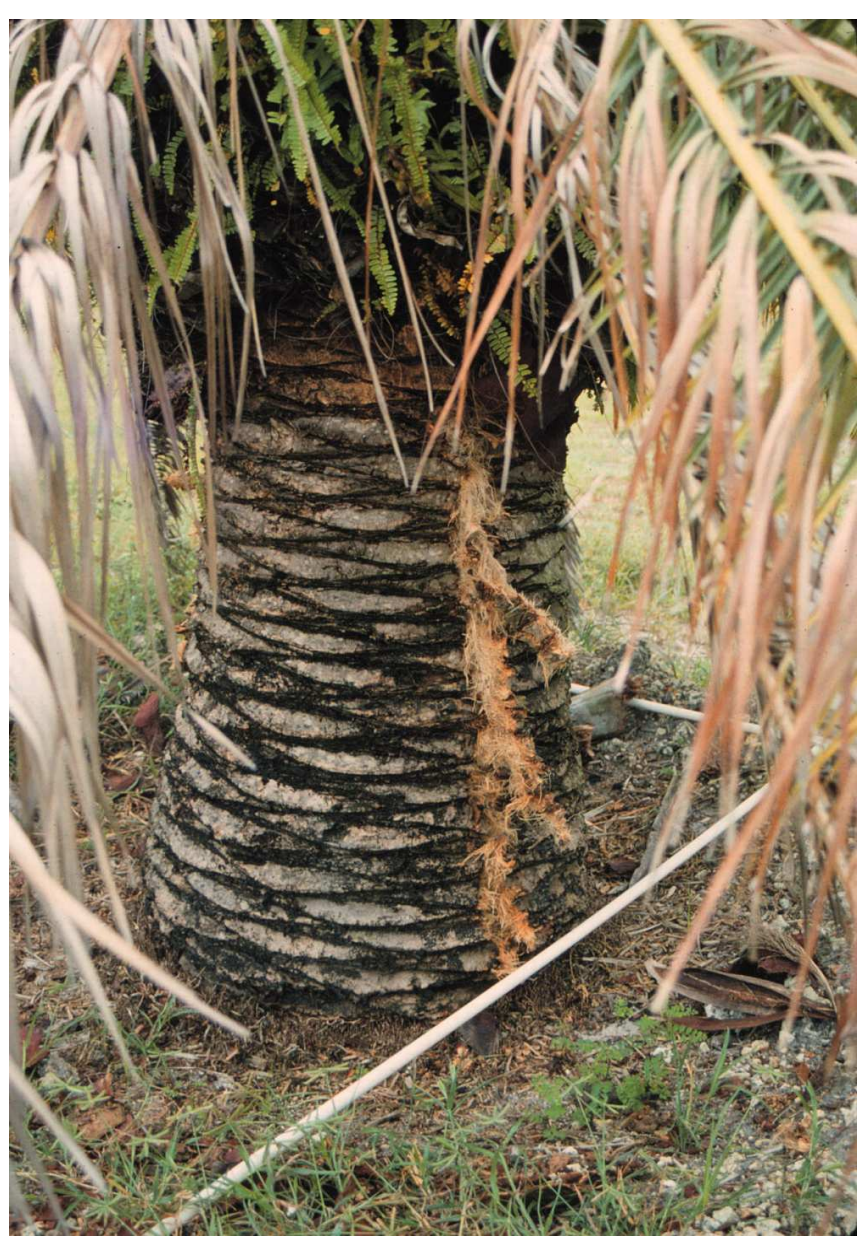

Figure 22. Trunk of Phoenix canariensis struck by lightning. Credits: T.K. Broschat

\section{Powerline Decline}

\section{Symptoms}

Leaves near high voltage overhead power lines often exhibit chlorotic or necrotic tips (Figures 23-25). In severe cases, the entire crown may become chlorotic with necrotic leaf tips. Palm death is relatively rare, however.

\section{Cause}

Electromagnetic fields within 2 to 5 feet of a high voltage power line appear to cause injury to palm foliage. Leaves do not need to physically contact the wires for injury to occur and often occurs on the side of the palm opposite the wires as well as those nearest to the lines.

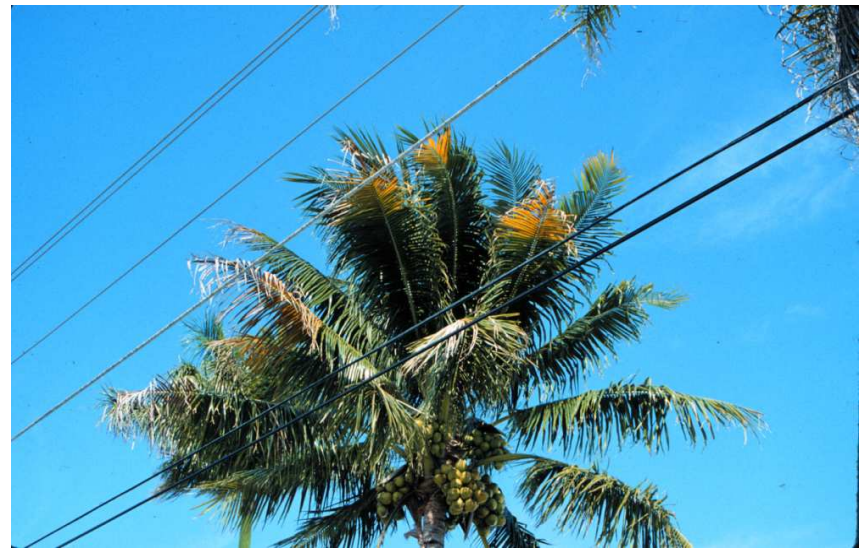

Figure 23. Powerline decline of Cocos nucifera. Note chlorotic leaf tips. Credits: T.K. Broschat

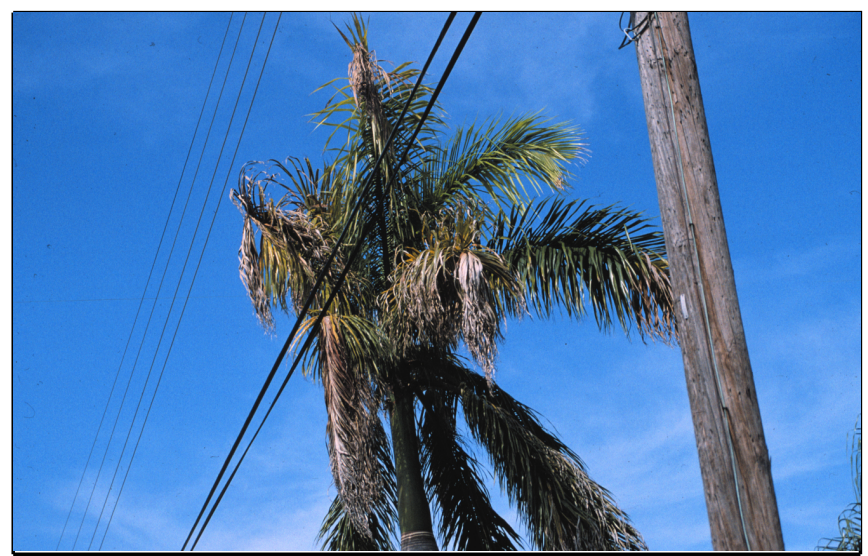

Figure 24.

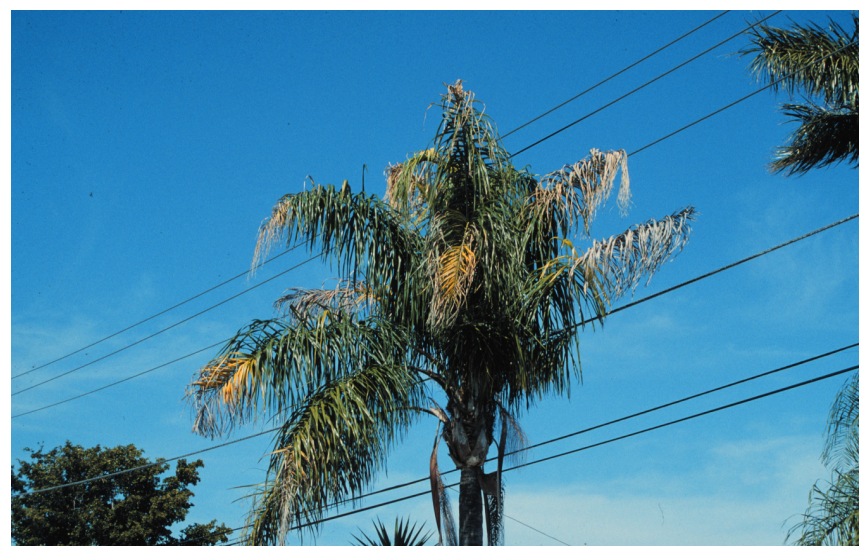

Figure 25. Powerline decline in Syagrus romanzoffiana. Credits: T.K. Broschat

\section{Occurrence}

Powerline decline is common wherever palms are planted under overhead power lines. Most species appear to be susceptible. 


\section{Diagnostic Techniques}

Visual symptoms on palms near overhead power lines is usually sufficient to diagnose this disorder.

\section{Management}

Avoid planting tall palms directly under or near overhead power lines. If a palm is growing directly under a power line, it should be removed, but if sufficiently far away that only leaf tips are affected, the palm may eventually grow above the lines and recover from the symptoms.

\section{Root Suffocation}

\section{Symptoms}

Early symptoms of root suffocation are often those of Fe deficiency, with chlorotic new leaves being produced (Figure 26). In severe cases, wilting of the foliage and shrinkage of the trunk may occur (see Figure 17). Roots may appear rotted. The root rot diseases that often result are secondary problems.

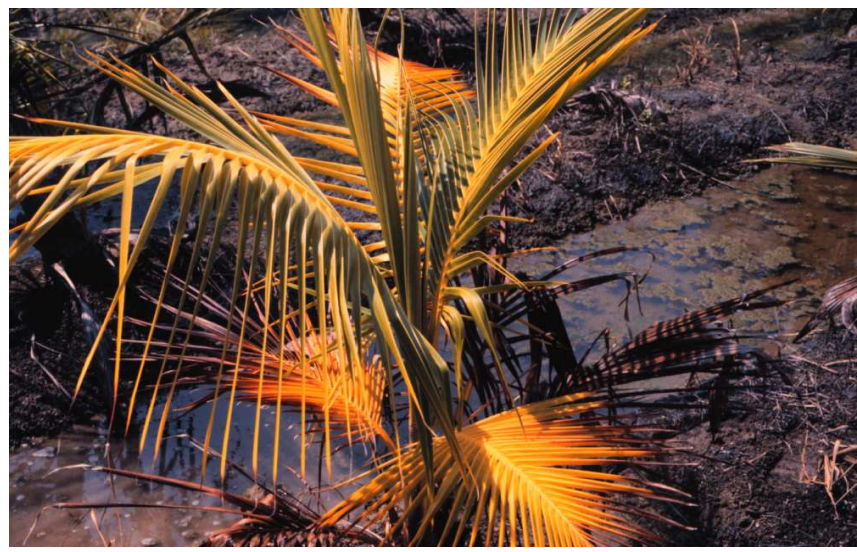

Figure 26. Poorly aerated soil causing root suffocation in Cocos nucifera. Credits: T.K. Broschat

\section{Cause}

Planting palms more deeply than they were originally growing decreases oxygen levels in the soil and can cause root suffocation. This can lead to eventual death of the root system and of the entire palm. Waterlogged soils also reduce soil aeration with similar effects on palm roots.

\section{Occurrence}

Palms in poorly-drained landscape or field sites, or in poorly-drained container substrates often suffer from this problem.

\section{Diagnostic Techniques}

Visual symptoms are usually adequate for diagnosis of this problem. Look for Fe or $\mathrm{Mn}$ deficiency symptoms, wilting, shriveling of the trunk, or excessive water in the root zone. Dig down to determine if the palm was planted too deeply.

\section{Management}

Deeply planted palms should be dug up and replanted at the proper depth. Poorly-drained sites should be built up with a berm prior to planting. There is no point in treating root rot disease without first correcting the primary reason for root suffocation.

\section{Selected References}

Broschat, T.K. 1995. Planting depth affects survival, root growth, and nutrient content of transplanted pygmy date palms. HortScience 30:1031-1032.

\section{Sunburn}

\section{Symptoms}

Large necrotic areas are visible on the upper surfaces of leaves, usually in the center of leaves or leaflets, rather than on the leaf tips or margins (Figure 27). Affected foliage on adjacent leaves will often have the same directional orientation.

\section{Cause}

Exposure of shade-grown foliage to high light intensities can injure leaves.

\section{Occurrence}

Sunburn can affect most species of palms.

\section{Diagnostic Techniques}

Visual symptoms alone are usually sufficient to diagnose this disorder. 


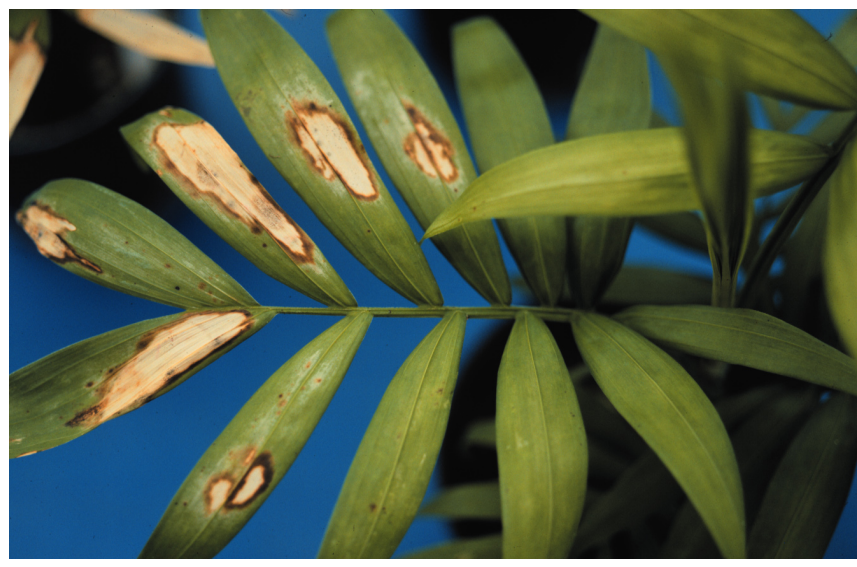

Figure 27. Sunburn injury on Chamaedorea elegans. Credits: T.K. Broschat

\section{Management}

Palms to be planted in a full sun location should be produced under full sun conditions. Individual leaves of shade-grown palms cannot adapt to high light intensities, but must be replaced by new leaves produced under, and adapted to, high light intensity.

\section{Water Stress}

\section{Symptoms}

Typical water stress symptoms include reduced growth and necrosis of leaflet tips, spreading to the entire leaf as severity increases (Figure 28). Oldest leaves are usually the first to show symptoms, but eventually newly emerging leaves may also wither and die. Death of the meristem or bud may follow. Water stress in some species is indicated by leaflets folding about the midrib or wilting. In mature palms, shriveling or collapse of the trunk may also occur (See Figure 17).

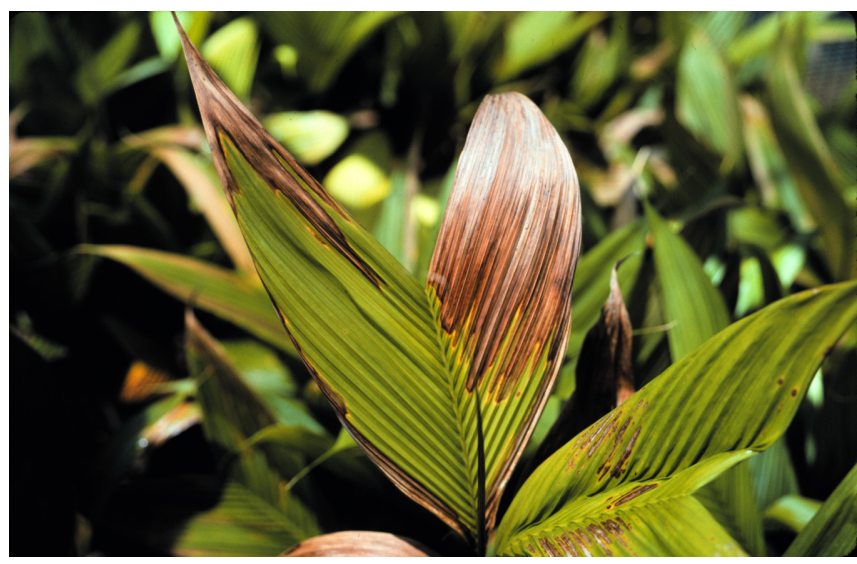

Figure 28. Water stress on Geonoma sp. Credits: T.K. Broschat

\section{Cause}

Water stress occurs when water is limiting or the root system is incapable of taking up sufficient water.

\section{Occurrence}

Water stress is fairly common in container-grown palms, but is less common in landscape or field situations due to the more extensive root systems of the latter. Wilting caused by water stress may be apparent on palms growing in wet soils due to root rot diseases, poor soil aeration, or vascular wilt diseases. Palm species native to dry climates are usually more drought tolerant than those from tropical rain forests that lack a distinct dry season. Palms in general are fairly tolerant of drought once established in the landscape.

\section{Diagnostic Techniques}

Visual symptoms are usually sufficient to diagnose this problem.

\section{Management}

Water stress is easily prevented by not allowing the soil to become excessively dry. Mildly stressed palms will usually recover when watered and lose only some of the oldest leaves, but severely stressed palms of sensitive species may die.

\section{Wind Damage}

\section{Symptoms}

Leaves of wind susceptible species appear tattered, often with only leaflet midveins remaining (Figure 29). Petioles of individual leaves anywhere within the canopy may snap and hang down (Figure 30). These may or may not remain green. In severe wind storms, palms may be uprooted, or the trunk will snap off at varying distances above the ground.

\section{Cause}

High winds from storms can damage foliage of susceptible species or snap or uproot other palms. Biotic stresses such as boring insects, woodpeckers, or trunk rotting fungi can predispose palms to snapping off from wind. 


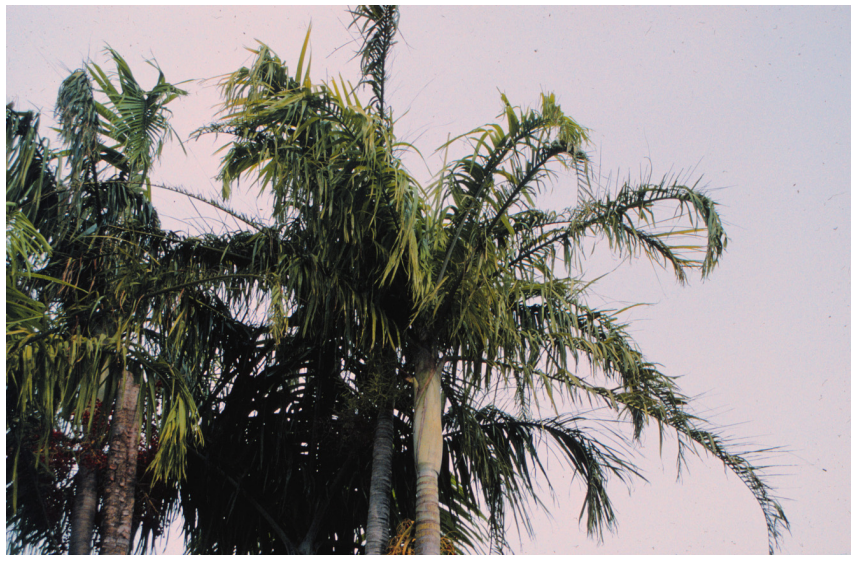

Figure 29. Wind damage on Carpentaria acuminata showing tattered leaflets. Credits: T.K. Broschat

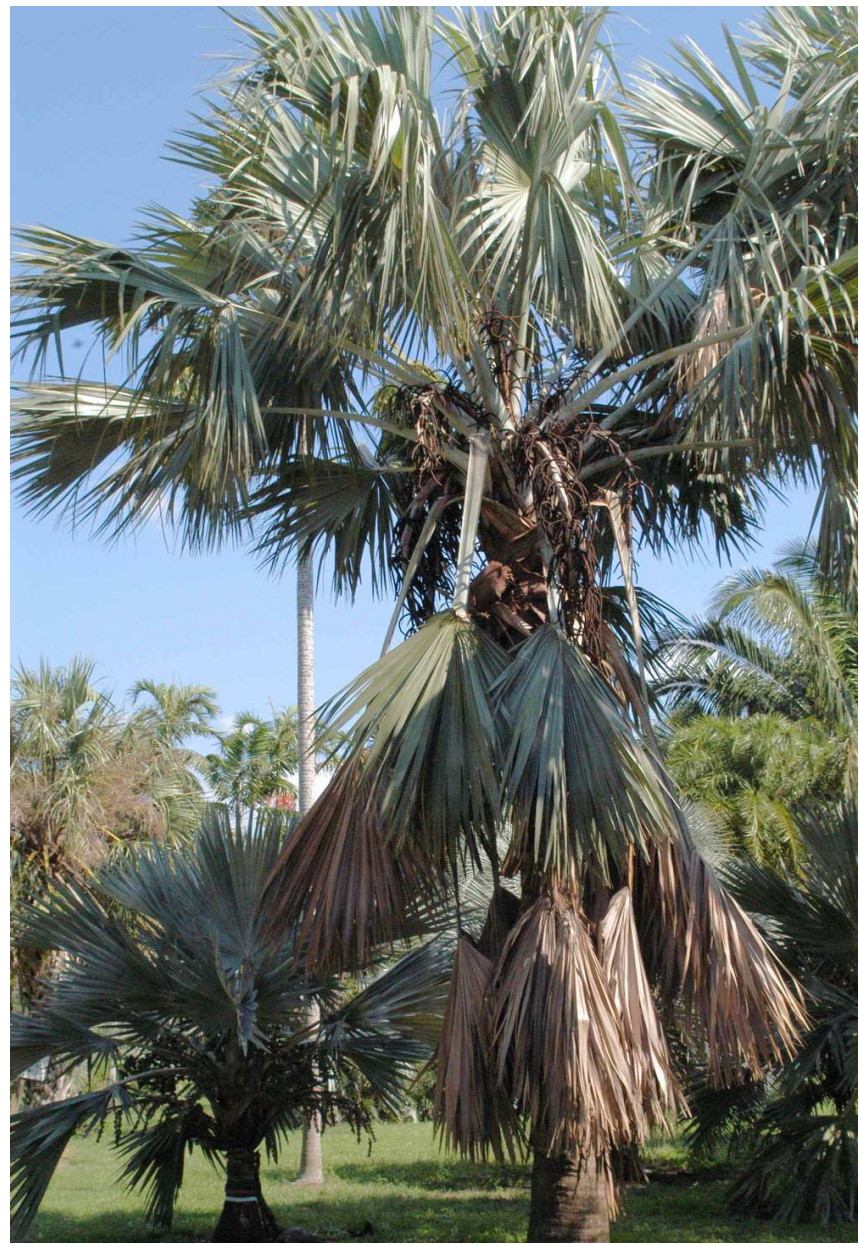

Figure 30. Broken petioles on Bismarckia nobilis caused by high winds. Credits: T.K. Broschat

\section{Occurrence}

Foliar damage is fairly common in species such as Carpentaria acuminata (Carpentaria palm) and Pigafetta filaris that have rather soft foliage. Toppling or snapping of palm trunks is rather rare except in localized areas that have experienced severe wind storms. However, individual leaves may snap in most species after experiencing winds of only moderate strength.

\section{Diagnostic Techniques}

Tattered foliage can easily be attributed to wind damage, while palms that snap off at or above the soil line may also have structural damage caused by boring insects, woodpeckers, or trunk rotting diseases such as Ganoderma butt rot or Thielaviopsis trunk rot.

\section{Management}

Do not plant wind susceptible palms such as Carpentaria acuminata or Pigafetta filaris in areas that regularly receive strong winds. Broken, but still green individual leaves may be removed unless they are the only foliage remaining after a severe storm. These should then be left on until the palm grows several new leaves to replace them. Palms that are uprooted by wind storms can usually be righted and braced. They will usually recover if righted within a few days after falling if the root system is kept moist. Treat these righted palms as though they were recent transplants. 